Original Research Paper

\title{
KKN Tematik Unram 2021 Melakukan Program Rakam Cerdas di Paud Al- Falaah Dusun Batu Belek Barat, Kelurahan Rakam, Kecamatan Selong, Lombok Timur
}

\author{
Ahmad Jupri ${ }^{1 *}$, Evita Hayati Kususma Putri ${ }^{2}$ Imran Raniatun ${ }^{3}$, Nia Ihwani ${ }^{4}$ \\ ${ }^{1}$ Prodi Ilmu Lingkungan FMIPA Unram \\ ${ }^{2}$ Prodi Akuntansi, Fakultas Ekonomi dan Bisnis Unram \\ ${ }^{3}$ Prodi Agribisnis, Fakultas Pertanian Unram \\ ${ }^{4}$ Prodi Sosiologi, Fakultas Ilmu Sosial dan Ilmu Politik Unram
}

https://doi.org/10.29303/jpmpi.v3i2.932

Sitasi: Jupri, A., Putri, E. H. K., Raniatun, I \& Ihwani, N. (2021). KKN Tematik Unram 2021 Melakukan Program Rakam Cerdas di Paud Al-Falaah Dusun Batu Belek Barat, Kelurahan Rakam, Kecamatan Selong, Lombok Timur. Jurnal Pengabdian Magister Pendidikan IPA, 4(3)

\section{Article history}

Received: 31 Juli 2021

Revised: 6 September 2021

Accepted: 7 September 2021

*Corresponding Author

Ahmad Jupri, Prodi Ilmu Lingkungan FMIPA Unram, Mataram, Indonesia;

Email: juprizikril@gmail.com

\begin{abstract}
Abstrak: Pendidikan merupakan salah satu kebutuhan manusia untuk bisa berproses dan berinteraksi di dunia luar dengan semua masyarakat sekitarnya. Pendidikan juga menjadi salah satu bekal terpenting di masa depan. Pendidikan itu sudah kita kenal sejak zaman sebelum Negara Indonesia merdeka hingga saat ini. Pendidikan menjadi salah satu hal pokok yang harus dipehatikan karena pendidikan mampu membentuk karakter pribadi setiap orang apabila sungguh-sungguh dalam menekuninya. Pendidikan adalah proses pembelajaran tentang akhlak, ilmu pengatahuan dan keterampilan yang menjadi kebiasaan turun-temurun sekelompok orang untuk melakukan pengajaran, pengamatan, pelatihan atau penelitian. Disinilah kami sebagai mahasiswa yang melakukan KKN ikut berpartisipasi dan mengajarkan kepada masyarakat akan pentingnya pendidikan, dengan cara membuat program Rakam Cerdas yang tujuannya yaitu utk mengajarkan masyarakat akan pentingnya menjaga protokol kesehatan dan menjaga lingkungan agar tetap bersih pada saat pandemi Covid-19.
\end{abstract}

Kata Kunci: Pendidikan, Program, Rakam, Cerdas, PAUD

\section{Pendahuluan}

Masuknya Virus Corona di Indonesia membawa dampak besar terhadap kehidupan masyarkat mulai dari Kehidupan Kesehatan, ekonomi Sosial, Keagamaan maupun dunia Pendidikan Dampak Virus Corona dalam dunia Pendidikan terlihat pada kebijakan Pemerintah Pusat hingga Pemerintah Daerah memberikan kebijakan untuk meliburkan seluruh lembaga Pendidikan dari tingkat Pendidikan Anak Usia Dini (PAUD) sampai Perguruan Tinggi. Hal ini dilakukan sebagai upaya mencegah meluasnya penularan Virus Corona. Diharapkan dengan seluruh lembaga Pendidikan tidak melakukan aktivitas tatap muka. Hal ini menuntut para Pendidik untuk lebih kreatif mengelola Pembelajaran secara Online. Sehingga proses Pembelajaran tetap berlangsung. Tidak terkecuali Pendidikan Anak Usia Dini (PAUD) Guru harus dituntut lebih kreatif, dalam mengelola Pembelajaran dimasa Pandemi Covid-19 ini.

Melihat kondisi sistem Pembelajaran saat ini banyak ditemui dilapangan lembaga Pendidikan Anak Usia Dini (PAUD) yang belum memungkinkan untuk melakukan sistem belajar secara Online atau Jarak Jauh dikarnakan banyak kendala dan belum mampunya Anak-anak atau Orang Tua dalam mengoperasikan Gedget atau 
Media Teknologi dan masih banyak kendala lainnya.

Sedangkan Perkembangan kemampuan belajar pada Anak Usia Dini masih dalam tahap untuk meniru. Anak belajar dari apa yang dilihat dan didengar. Dan prinsip belajar pada Pendidikan Anak Usia Dini (PAUD) yakni belajar sambil bermain, banyak juga orang tua mengatakan bahwa anak-anak lebih menyukai dan lebih melakukan kegiatan belajar bersama teman-temannya dan guru. Diakarenakan orang tua anak biasanya malah dibentak-bentak yang juga efeknya kurang bagus bagi anak.

\section{Metode}

\section{Waktu dan Tempat}

Kegiatan program Rakam Cerdas ini dimulai pada tanggal 24 Juni 2021 sampai dengan Agustus 2021, dilakukan di Paud Al-Falaah Dusun Batu Belek Barat, Kelurahan Rakam, Kecamatan Selong, Lombok Timur.

\section{Kegiatan}

Bentuk kegiatan dalam program Rakam Cerdas ini mencoba untuk mengajarkan dan memberitahu pentingnya menjaga dan melindungi diri kita dari bahaya covid-19. Mengingat pada Era New Normal ini, pentingnya mematuhi protokol yang ada, juga tentu menjaga imun tubuh tetap terpenuhi. Berangkat dari pemikiran itu, kami membuat beberapa kegiatan dalam program Rakam Cerdas ini yaitu :

a. Mahasiswa KKN Tematik Unram melakukan kegiatan bagi-bagi masker.

b. Mahasiswa KKN Tematik Unram melakukan kegiatan jalan-jalan sehat.

c. Mahasiswa KKN Tematik Unram melakukan kegiatan senam.

\section{Hasil dan Pembahasan}

Dalam program Rakam Cerdas ini kami selaku Mahasiswa KKN Tematik Unram melakukan kegiatan seperti bagi-bagi masker, Jalan sehat, dan Senam. Yang pertama kegiatan bagi masker yang dilaksanakan pada hari Selasa, 13 Juli 2021, Dalam kegiatan ini kita membagikan masker kepada seluruh murid yang ada di PAUD Al-Falaah dan mengajarkan mereka cara menggunakan masker yang benar dan dampak dari tidak menggunakan masker pada massa pandemi covid19 ini.

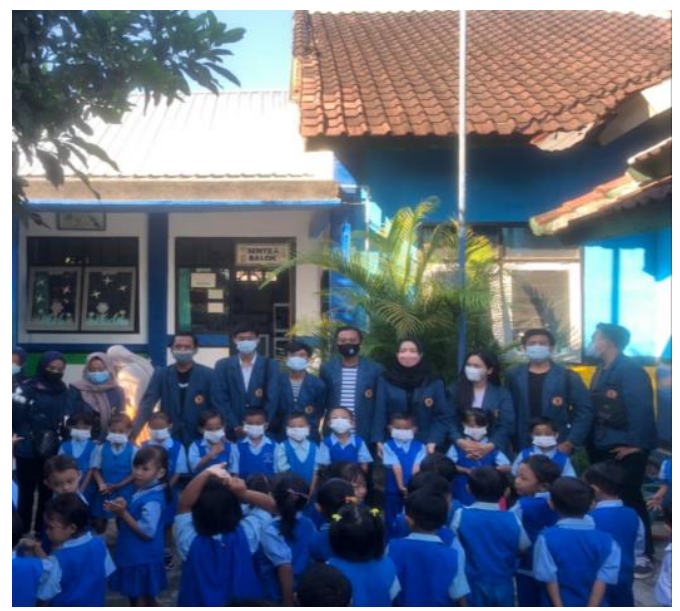

Kegiatan yang kedua yaitu jalan sehat padi hari Sabtu, 17 Juli 2021, Dalam jalan sehat ini kami mengajak seluruh murid dalam ikut serta dalam jalan sehat. Kegiatan jalan sehat ini untuk mengajarkan kepada anak-anak Paud untuk melihat lingkungan sekitar mereka dan untuk mengajarkan pentingnya kebersihan lingkungan serta pentingnya menjaga alam sekitar.

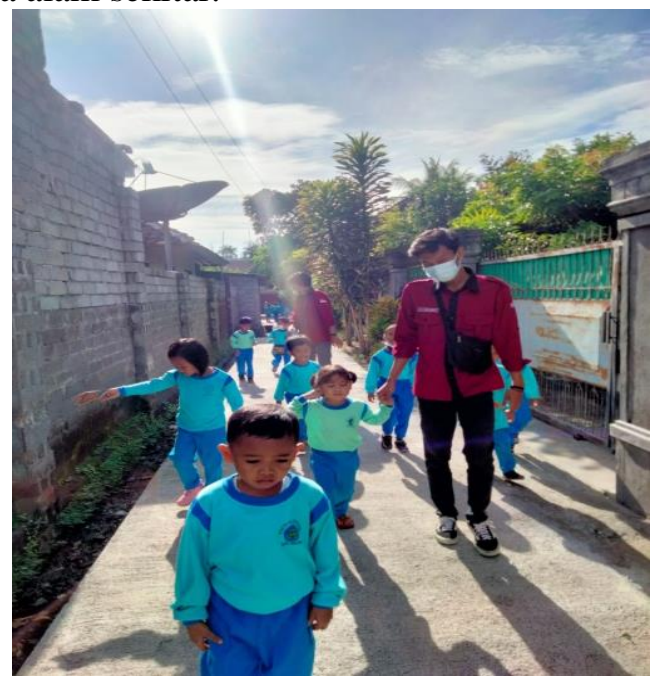

Kegiatan yang terakhir yaitu melakukan kegiatan senam bersama anak-anak Paud beserta guru-guru yang dilaksanakan pada hari Sabtu, 17 Juli 2021 di Paud Al-Falaah, Dalam program Kegiatan senam ini banyak sekali manfaatnya terutama untuk menjaga kebugaran, menambah kukuatan dan kelenturan, serta meningkatkan daya tahan tubuh. 


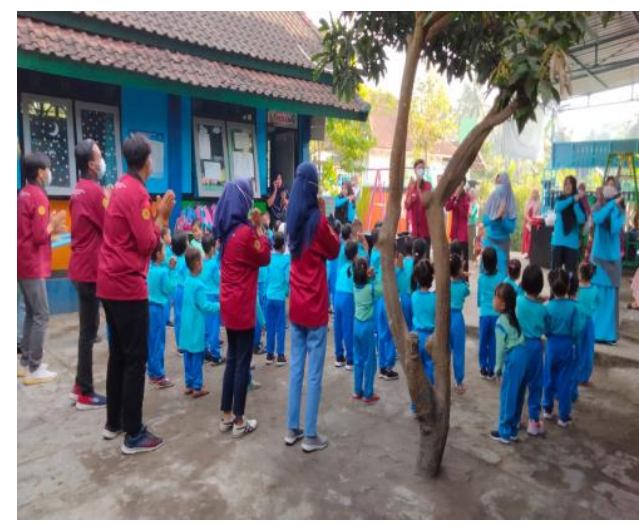

\section{Kesimpulan}

Program Rakam Cerdas ini bertujuan untuk mengajarkan dan memberitahu akan pentingnya menjaga kesehatan tubuh dan lingkungan pada masa Era New Normal ini, kegiatan tersebut juga untuk membantu anak-anak murid Paud Al-Falaah bisa mengerti akan bahayanya covid-19 apabila tidak mematuhi protokol kesehatan. Kegiatan yang dilakukan dalam program Rakam Cerdas ini yaitu, (1) melakukan kegiatan Bagi-bagi Masker, (2) melakukan kegiatan Jalan-jalan Sehat, (3) melakukan kegiatan Senam. Kegiatan yang kami lakukan selama KKN ini mudah-mudahan bisa diterima dan dijalankan dalam kehidupan seharihari, dan juga bisa bermanfaat dan memotivasi masyarakat yang berada di Kelurahan Rakam, khusunya di Dusun Batu Belek Barat.

\section{Daftar Pustaka}

https://disdikpora.bulelengkab.go.id/informasi/ detail/artikel/56-efektifitaspembelajaran-anak-usia-dini-di-masapandemi

http://formadiksi.um.ac.id/sejarah-pendidikanindonesia-dari-masa-ke-masamembentuk-karakter-pribadi-pribumibangsa/ 